\title{
PERKEMBANGAN KESENIAN BARONG DI DESA KEMIREN
}

\author{
KABUPATEN BANYUWANGI \\ Lukman $^{1}$, Tian Fitriara Huda ${ }^{2}$ \\ Fakultas Keguruan dan Ilmu Pendidikan, Universitas PGRI Banyuwangi ${ }^{1}$ \\ Email: pradanaluck14@yahoo.co.id \\ Email: tianfitriarahuda@gmail.com
}

\begin{abstract}
Kesenian Barong Kemiren Banyuwangi merupakan salah satu ritual adat masyarakat Using di bumi Blambangan yang terletak di Desa Kemiren. Ritual ini bersifat sakral sekaligus mistik. Namun, kesakralan upacara tersebut sedikit berkurang karena ritual Adat ini merupakan salah satu wisata Kesenian di Kemiren. Belakangan ini, ritual yang tadinya bersifat sangat sakral sedikit berubah menjadi sebuah kesenian yang menonjolkan sisi artistiknya. Salah satu keunikan Barong Ider Bumi dan menjadi suatu kebanggan tersendiri bagi masyarakat Using adalah "kesurupan". Namun di dalam perkembangannya saat ini, banyak masyarakat yang masih belum mengetahui tentang sejarah dan perkembangan ritual sakral ini dari masa lampau hingga sekarang

Peneliti menggambil data di Kecamatan Kemiren Tresno Budoyo. Peneliti menggunakan Metode deskriptif kualitatif dengan teknik pengumpulan data yaitu observasi, wawancara dan dokumentasi.
\end{abstract}

Kata kunci : Kesenian, Tradisi, Perkembangan, Barong Tresno Budoyo, Banyuwangi

\begin{abstract}
ABSTRAK
Barong Tresno Budoyo Kemiren Banyuwangi is one of the customary rituals of the people of Using in Blambangan earth located in Kemiren Village. This ritual is both sacred and mystical. However, the sacredness of the ceremony was slightly reduced because this customary ritual was one of the art tours in Kemiren. Lately, rituals that were once very sacred have changed a little to an art that emphasizes its artistic side. One of the uniqueness of the Earth Barong Ider and being a pride for the Using community is "possessed". But in its current development, many people still do not know about the history and development of this sacred ritual from the past to the present

Researchers took data in Kemiren Tresno Budoyo sub-district. The researcher used qualitative descriptive method with data collection technique that is observation, interview and documentation.
\end{abstract}

Keywords: Art, Tradition, Development, Barong Tresno Budoyo, Banyuwangi

1. Pendahuluan

Banyuwangi adalah kabupaten yang berada

di ujung timur propinsi Jawa Timur yang memiliki potensi kepariwisataan cukup

melimpah akan adat, budaya, dan suku serta 
memiliki kultur dan etnik beranekaragam. Keberagaman itu dapat dilihat berdasarkan kultur masyarakatnya secara dominan terbagi kedalam tiga etnik yaitu etnik Jawa Mataraman, etnik Madura Pandalungan, danetnik Using. Keaneragaman etnis masyarakat tersebut melahirkan kekayaan budaya yang menjadi identitas diri tidak terhitung nilainya .

Menurut Koentjaraningrat (2004:30), di lingkungan pedesaan, keanekaragaman warna masyarakat dan juga kebudayaan Indonesia masih tetap terjaga, sehingga perbedan kebudayaan - kebudayaan yang ada dari beragam suku bangsa hingga sekarang masih terlihat mencolok. Kebudayaan tersebut merupakan hasil karya cipta dari pemikiran, perasaan dan nurani manusia. Hasil dari ini semua, akan membentuk kebudayaan yang membuat setiap kelompok-kelompok manusia memiliki ciri-ciri yang berbeda. Kebudayaan tersebut biasanya digunakan sebagai sarana komunikasi dalam kehidupan mereka, baik komunikasi antara invididu maupun komunikasi antara manusia dengan alam sekitarnya.

Kebudayaan masyarakat mencakup berbagai macam aspek dalam kehidupan. Salah satu kebudayaan yang dimiliki oleh masyarakat
Indonesia adalah kesenian tradisional. Setiap daerah tentunya memiliki ciri khas kesenian tradisional yang berbeda satu dengan yang lainnya. Kesenian tradisional itu dapat mencakup seni tari, seni rupa, seni musik, dan lainnya.

Kesenian merupakan salah satu dari ketujuh unsure kebudayaan yang mempunyai wujud, fungsi, dan arti dalam kehidupan masyarakat. Bentuk-bentuk kesenian yang tersebar di seluruh tanah air menunjukkan corak-corak dan karakter yang beranekaragam. Corak atau karakter tersebut muncul karena banyak dipengaruhi oleh sifat atau karakter budaya setempat, darimana masyarakat berasal atau bertempat tinggal. Kesenian berperan sebagai media komunikasi, sehingga suatu bentuk kesenian yang akan lahir, tumbuh dan berkembang berdasar situasi maupun kondisi masyarakat di mana kesenian tersebut menampakkan eksistensinya. Sepanjang sejarah kehidupan manusia, seni selalu hadir sebagai unsure kebudayaan yang penting. Hal ini disebabkan seni memiliki daya ekspresi sehingga mampu merefleksikan secara simbolik komunikasi untuk berekspresi, menyampaikan pesan, kesan dan tanggapan manusia terhadap stimulasi dari lingkungan. (Setyorini, 2013:1\&2). 
Kesenian di Banyuwangi mempunyai beragam bentuk, salah satunya seni pertunjukan. Dalam seni pertunjukan terdapat beberapa cabang seni, diantaranya adalah : seni musik, seni tari, seni rupa, seni drama, dan seni sastra. Salah satu Desa di Banyuwangi yang kini dijadikan sebagai Desa Adat yaitu Desa Kemiren. Masyarakat desa kemiren mayoritas adalah etnik Using. Sebagai desa Adat Kemiren memliki banyak kesenian yang menjadi aset kebudayaan asli Banyuwangi. Salah satu kesenian yang terkenal yaitu Kesenian Barong Kemiren Banyuwangi.

Barong Tresno Budoyo d Kemiren adalah satu-satunya grup kesenian yang masih tetap eksis di era modern ini.Grup kesenian ini berkembang sangat pesat sehingga banyak orang yang mendirikan Grup barong baru bermunculan Di Desa Kemiren, Barong berfungsi secara sacral maupun profan. Fungsi secara sakral, barong digunakan sebagai selametan Ider Bumi yaitu selametan bersih desa yang diadakan setiap 2 Syawal dalam kalender Hijriah. Pada ritual ini, barong dan sejumlah perangkatnya diarak keliling kampung sebagai wujud syukur masyarakat desa atas barokah yang melimpah pada kehidupannya selama setahun.
Kesenian Barong Kemiren Banyuwangi merupakan salah satu ritual adat masyarakat Using di bumi Blambangan yang terletak di DesaKemiren. Ritual ini bersifat sacral sekaligus mistik. Salah satu keunikan Barong Ider Bumi dan menjadi suatu kebanggan tersendiri bagi masyarakat Using adalah "kesurupan”.Namun di dalam perkembangannya saat ini, banyak masyarakat yang masih belum mengetahui tentang sejarah dan perkembangan ritual sacral ini dari masa lampau hingga sekarang.Berangkat dari uraian di atas, maka penulis ingin melakukan penelitian yang berjudul "Kesenian Barong Kemiren banyuwangi".

\section{Kajian Literatur dan Pengembangan Hipotesis}

\subsection{Kebudayaan}

Indonesia kaya akan budaya, istiadat dan tradisi, maupun seni yang dimiliki merupakan karya budaya pendahulu kita. Menurut Koentjaraningrat dalam Sulistyanto (2012:1), bahwa kebudayaan itu mempunyai tiga wujud yaitu: yang pertama sebagai suatu kompleks dari ide-ide, gagasan, nilainilai, norma-norma, peraturuan. Yang kedua, kebudayaan sebagai suatu kompleks aktivitet kelakuan berpola dari manusia dalam masyarakat. Dan yang ketiga, wujud kebudayaan sebagai benda-benda hasil karya 
manusia. Kebanyakan orang hanya mengenal sebatas hiburan tanpa mengetahui makna sebenarnya tentang budaya.

Menurut Suparlan dalam Made

Karthadinata

(2006:12)

kebudayaanadalahsesuatu yang bersifatabstrak, yaitupedomanmenyeluruh yang berisisistem-system pengetahuan, sistem-sistem kepercayaan, sistem-sistem gagasan dan sistem-sistem nilai bagi segala tindakan manusia dalam memenuhi kebutuhan hidupnya. Kebudayaan ada, berkembang, dan dibakukan dalam tradisitradisi social suatu masyarakat.Kebudayaan adalah milik masyarakat yang dipergunakan secara bersama, sebagai pedoman atau kerangka acuan warga masyarakat yang bersangkutan dalam berbagai tingkah laku yang bertalian dengan upaya untuk memenuhi kebutuhan hidupnya.Kendati dalam kenyataan empiric pada tingkati ndividu dimungkinkan terjadi penyimpangan tingkah laku sebagai akibat pengetahuan kebudayaan yang dimiliki.

\subsection{Seni Barong Tresno Budoyo}

Seni berasal dari bahasa Melayu yang berarti kecil. Seni adalah keindahan dan seni adalah tujuan yang positif menjadikan penikmat merasa dalam kebahagiaan. Seni adalah bentuk yang pengungkapannya dan penampilannya tidak pernah menyimpang dari kenyataan dan seni itu adalah meniru alam. Seni adalah sebuah impian karena rumus-rumus tidak dapat mengihtiarkan kenyataan

Karya seni merupakan sebuah benda atau artefak yang dapat dilihat, didengar, atau dilihat dan sekaligus didengar (visual, audio, dan audio-visual), seperti lukisan, music dan teater (Sumardjo, 2000:45).

\section{Metode Penelitian}

Metode penelitian menggunakan metode deskriptif kualitatif yaitu dengan cara menguraikan dan menggambarkan aspek yang diteliti. Penelitian kualitatif data yang diperoleh berupa kata-kata melalui informasi dari para pendukung, tulisan, dan foto. Metode deskriptif adalah tehnik pengumpulan data yang berupa kata-kata, gambar, dan bukan angka-angka. Data yang dikumpulkan dapat berupa naskah wawancara, catatan lapangan, foto, vidiotape, dokumentasi pribadi, catatan atau memo, dan dokumentasi resmi lainnya (Moleong, 2011 : 11). Selain itu observasi menjadi teknik pengambilan data dilapangan dengan cara melakaukan pengamatan dilapangan (Agus Mursidi, 2016:96) . 
Data yang diperoleh dengan wawancara mendalam dengan berbagai pihak yang bersangkutan. Setelah itu data yang diperoleh kemudian dapat dikelola dan dianalisis, serta data tersebut dipilah-pilah disesuaikan dengan pembahasan.. Selanjut mendiskripsikan dan disimpulkan. Peneliti juga menggunakan metode Trianggulasi untuk menguji keabsahan data, sehingga dapat memperkuat data, untuk membuat peneliti yakin tentang kebenaran dan kelengkapan data. Penelitian ini bertujuan untuk mendeskripsikan tentang budaya kesurupan seni tradisi barong banyuwangi yang berada Kabupaten Banyuwangi Provinsi Jawa Timur

\section{Daftar Pustaka}

Karthadinata， Dewa Made. 2006. Barong Ket dan Rangda : Kajian Tentang. Perkembangan, Proses Pembuatan, dan Sakralisasi, serta Pesan-pesan. Budaya. Semarang : UNNES

Koentjaraningrat. 2004. Kebudayaan, Mentalitas dan Pembangunan. Jakarta : PT. Gramedia. Pustaka Utama.

Moleong, Lexy.J. 2002.Metodelogi penelitian kualitatif. Bandung. Remaja Rosda Karya.
Moleong, Lexy.J. 2007 Metodologi Penelitian Kualitatif, Penerbit PT Remaja Rosdakarya Offset, Bandung. Mursidi, Agus, 2016. Dominasi Kiai Dalam Pendidikan di pondok Pesantren Ihya'ulumiddin. Historia Volume 4, nomor 2. UMM Metro

Setyorini.2013.Kesenian Kuda Lumping Di Tinjau Dari Perspektif. Jakarta : PT. Gramedia. Pustaka Utama.

Sumardjo, Jakob, 2000. Filsafat Seni, Bandung : Penerbit ITB, 